Inquiry Training, Oleh: Moh. Turmudi

\title{
INQUIRY TRAINING: DARI FAKTA KE TEORI
}

\author{
Moh. Turmudi*
}

\begin{abstract}
Abstrak
Pembelajaran Inkuiri merupakan model pembelajaran untuk meningkatkan hasil pembelajaran di sekolah. Model pembelajaran ini digunakan untuk melakukan pembelajaran dengan pengalaman nyata yang dihadapi oleh siswa di sekolah.Pembelajaran dilakukan secara mandiri sehingga siswa mampu menemukan beberapa hal yang berhubungan dengan materi pembelajaran.

Pembelajaran inkuiri merupakan kegiatan pembelajaran yang melibatkan secara maksimal seluruh kemampuan siswa untuk mencari dan menyelidiki sesuatu (benda, manusia atau peristiwa) secara sistematis, kritis, logis, analitis sehingga mereka dapat merumuskan sendiri penemuannya dengan penuh percaya diri.
\end{abstract}

Kata Kunci: Inquiry, Training

\section{Pendahuluan}

Pembelajaran Inkuiri telah dikembangkan oleh Richard Suchman untuk mengajari para siswa sebuah proses penyelidikan dan sebuah fenomena yang luar biasa. Model ini mengajak siswa melalui prosedur mini yang digunakan untuk mengorganisasikan pengetahuan dengan menghasilkan prinsip-prinsip. ${ }^{1}$ Berdasarkan pengertian ilmiah, Pembelajaran Inkuiri adalah upaya untuk mengajar siswa beberapa keterampilan dan bahasa inkuiri ilmiah.

Suchman mengembangkan modelnya dengan menganalisis metode yang digunakan oleh ahli penelitian yang kreatif terutama untuk ilmuwan fisik. Sebagaimana ia mengidentifikasi elemen-elemen dari proses penyelidikannya, dia membangun elemen-elemen tersebut dalam

\footnotetext{
* Dosen Tetap Institut Agama Islam Tribakti Kediri

${ }^{1}$ B.Joice, \& Weil, M., Model of Teaching Englewood ellifts (N.J. : Prentice Hall Inc. 1980). h.62
} 
Inquiry Training, Oleh: Moh. Turmudi

bentuk model pembelajaran yang disebut Inquiry Training (Pembelajaran Inkuiri). ${ }^{2}$

\section{Orientasi Model}

\section{Tujuan dan Asumsi}

Pembelajaran Inkuiri berangkat dari keyakinan pada perkembangan pembelajar mandiri, metodenya memerlukan partisipasi aktif dalam inkuiri ilmiah. Anak ingin tahu dan ingin berkembang, serta pembelajaran inkuiri menekankan pada eksplorasi energetik alamiah anak, memberikan arah secara khusus, sehingga hal-hal baru akan tergalih secara mendalam. Tujuan umum pembelajaran inkuiri adalah mendorong para siswa mengembangkan disiplin intelektual dan keterampilan bertanya dan mencari jawaban yang keluar dari rasa keingintahuannya. Jadi, Suchman tertarik untuk membantu siswa dengan memberikan pembelajaran yang bebas teta Pembelajaran Inkuiri dengan cara disiplin. Dia menginginkan siswa bertanya mengapa suatu kejadian terjadi sebagaimana mereka mengerjakan dan memperoleh serta memproses data secara logis, dan dia ingin mereka untuk mengembangkan strategi intelektual umum yang dapat mereka gunakan untuk mencari tahu mengapa segala sesuatu itu sebagaimana adanya.

Pembelajaran Inkuiri dimulai dengan memberikan siswa dengan teka-teki peristiwa. Suchman percaya bahwa individu jika berhadapan dengan situasi seperti itu secara alamiah termotivasi untuk memecahkan teka-teki. Kita dapat menggunakan kesempatan yang diberikan oleh inquiri alami untuk mengajarkan prosedur disiplin pencarian.

Seperti Bruner, Taba, dan Ausubel, Suchman percaya bahwa siswa dapat semakin memanfaatkan kemampuan proses inkuiri dan mereka dapat diajari prosedur ilmiah secara langsung. Kita semua sering ingin mengetahui berdasarkan intuisi, namun Suchman merasa kita tidak dapat menganalisis dan meningkatkan pemikiran kita kecuali kita sadar akan hal itu. ${ }^{3}$

Suchman mengatakan siswa perlu memiliki sikap bahwa semua pengetahuan adalah tentatif (tidak pasti). Peneliti membuat teori dan

${ }^{2}$ Dalam Slavin, Robert. E. Cooperative Learning; Teori, Risetdan Praktik. (Bandung: Nusa Media, 2008)

${ }^{3}$ Krismanto, M.Sc.. Beberapa Teknik, Model dan Strategi dalam Pembelajaran. (Yogyakarta: PPPG, 2003), h. 25

Vol. 22 Nomor. 1 Januari 2011 
Inquiry Training, Oleh: Moh. Turmudi

penjelasan. Beberapa tahun kemudian pandangan ini dikesampingkam oleh teori-teori baru. Tidak ada jawaban yang permanen. Kita selalu dapat dengan hal-hal baru yang lebih canggih dalam penjelasannya. Siswa harus mengakui dan merasa nyaman dengan ambiguitas sejati bahwa inkuiri diperlukan. Mereka harus menyadari bahwa bahwa pandangan kedua memperkaya pemikiran kita sendiri. Pengembangan pengetahuan difasilitasi oleh bantuan dan ide dari rekan-rekan jika kita dapat belajar untuk bertoleransi pada sudut pandang alternatif.

Adapun teori Suchman adalah:

1. Orang ingin mengetahui secara alami ketika mereka kebingungan.

2. Mereka dapat menjadi sadar akan sesuatu dan belajar menganalisis strategi pemikiran mereka.

3. Strategi-strategi baru dapat diajarikan secara langsung dan dapat ditambahkan dari yang sudah dimiliki siswa.

4. Inkuiri Kooperatif memperkaya pemikiran dan membantu siswa untuk mempelajari tentang tentatif (suatu usaha/percobaan), pengetahuan baru alami dan menghargai penjelasan alternatif. ${ }^{4}$

\section{Sekilas tentang Strategi Pengajaran}

Mengikuti keyakinan Suchman bahwa individu memiliki motivasi alami terhadap inkuiri, model pembelajaran inkuiri dibangun di atas pertentangan intelektual. Siswa dipajani dengan teta-teki situasional dan mencari jawabannya. Segala sesuatu yang misterius, tak terduga, atau tak diketahui merupakan digunakan untuk menjelaskan kejadian. Karena tujuan akhir menjadikan siswa memiliki pengalaman membangun pengetahuan, pertentangan harus didasarkan pada ide yang dapat ditemukan. Berikut contoh penekukan lepengan metal jika dipanasi diatas api merupakan episode memulai siklus inkuiri. ${ }^{5}$

Lempengan terbuat dari laminasi lempengan metal (baja atau tembaga) yang telah dilas menyatu membentuk satu bilah. Dengan sebuah pegangan yang membentuk sebilah pisau atau sepatula. Apabila alat ini dipanasi, metalnya akan mengembang tetapi pengembangannya

\footnotetext{
${ }^{4}$ Joice, B. \& Weil, M. Model of Teaching Englewood ellifts (N.J.: Prentice Hall Inc. 1980), h. 63

${ }^{5}$ Dalam Slavin, Robert. E. Cooperative Learning; Teori, Risetdan Praktik. (Bandung: Nusa Media, 2008)
}

Vol. 22 Nomor. 1 Januari 2011 
Inquiry Training, Oleh: Moh. Turmudi

berbeda pada kedua metal tersebut. Akibatnya salah satunya melengkung karena mengembang lebih besar.

Suchman memilih episode ini dengan sengaja yang menjadikan siswa bertanya-tanya. Siswa tidak dapat menjawab masalah ini. Mereka harus bekerja menjelaskan situasi tersebut. Hasil dari kerja mereka merupakan wawasan, konsep dan teori baru.

Setelah presentasi siswa bertanya pada guru. Pertanyaan harus dijawab dengan ya atau tidak. Siswa tidak boleh bertanya fenomena dari kejadian tersebut. Mereka harus fokus dan membangun struktur penyelidikan mereka untuk mencari jawaban dari masalah tersebut. Jadi siswa tidak boleh bertanya: "Bagaimana pengaruh panas pada metal?" tetapi boleh bertanya:"apakah panas lebih besar dari titik didih metal?". Apabila siswa tidak dapat membuat pertanyaan "Ya" atau "Tidak" guru mendorong mereka untuk membuat pertanyaan yang jawabanna "Ya" atau "Tidak" misalnya: "Dapatkan kamu mengulang pertanyaan itu dengan kata lain sehingga saya dapat menjawab "Ya" atau "Tidak". Dengan mengumpulkan fakta yang ada siswa akan membangun hipotesa untuk menjawab masalah yang diberikan.

\section{Model Pengajaran}

\section{Sintaksis}

Pembelajaran Inkuiri memiliki lima fase. Fase pertama siswa dihadapkan pada situasi berteka-teki. Fase kedua dan ketiga adalah pengumpulan data untuk verifikasi dan ekperimen. Pada kedua langkah ini siswa diberi pertanyaan-pertanyaan dengan jawaban "Ya" atau "tidak" dan mereka melakukan serangkaian percobaan terhadap lingkungan situasi masalah. Pada fase keempat siswa mengorganisasikan informasi yang diperoleh selama pengumpulan data dan mencoba untuk menjelaskan perbedaan tersebut. Akhirnya pada tahap lima, siswa merefleksikan strategi pemecahan masalah yang mereka gunakan selama penyelidikan.

Pada fase pertama, guru menyajikan masalah situsional dan menjelaskan prosedur inkuiri pada para siswa (tujuandan prosedur dari pertanyaan ya atau tidak). Fase kedua, adalah pengumpulan data dan verifikasi yaitu proses dimana siswa mengumpulkan informasi tentang suatu peristiwa yang mereka lihat atau pengalaman dalam percobaan.

Vol. 22 Nomor. 1 Januari 2011 
Inquiry Training, Oleh: Moh. Turmudi

Fase tiga, siswa memperkenalkan unsur-unsur baru ke dalam situasi untuk melihat sesuatu secara berbeda. Walaupun verifikasi dan eksperimentasi digambarkan sebagai fase yang terPembelajaran Inkuirisah dari model, cara berfikir siswa dan jenis pertanyaan yang mereka hasilkan biasanya antara kedua aspek pengumpulan databergantian. Fase keempat, guru mengajak siswa untuk merumuskan penjelasan. Siswa memformulasikan informasi yang diperoleh selama pengumpulan data dan mencoba untuk menjelaskan perbedaan. Beberapa siswa akan mengalami kesulitan dalam membuat lompatan intelektual antara informasi yang mereka kumpulkan dan penjelasan. Akhirnya pada fase lima, siswa diminta untuk menganalisis pola penyelidikan dengan menentukan pertanyaan yang paling efektif, garisgaris pertanyaan yang produktif dan yang tidak atau jenis informasi yang deperoleh dan tidak. Pada fase ini siswa merefleksikan pemecahan masalah dengan menganalisis strategi penyelidikan untuk mengembangkan yang lebih efektif. ${ }^{6}$

\section{Sistem Sosial}

Keinginan Suchman adalah bahwa sistem sosial bersifat kooperatif dan ketat. Meskipun Model Pembelajaran Inkuiri bisa sangat sangat terstruktur, dengan sistem sosial sebagian besar dikontrol oleh guru, lingkungan intelektual ini terbuka untuk semua ide yang relevan; guru dan siswa berpartisipasi setara dalam hal ide-ide. Selain itu, guru harus mendorong siswa untuk Memulai penyelidikan sebanyak mungkin. Pada saat siswa belajar prinsip-prinsip penyelidikan, struktur dapat diperluas dengan penggunaan sumber belajar, dialog dengan siswa lain, eksperimentasi, dan diskusi dengan guru.

Setelah periode praktek dalam sesi penyelidikan guruterstruktur, siswa dapat melakukan inkuiri dengan setting/pengaturan siswa lebih terkontrol. Sebuah peristiwa menantang dapat diatur di dalam ruangan, dan siswa dapat bertanya pada kelompok mereka sendiri atau dalam kelompok informal, bergantian antara sesi Inkuiri terbuka dan pengumpulan data / dengan bantuan bahan-bahan sumber daya. Dengan cara ini, para siswa dapat bergantian bolak-balik antara sesi

${ }^{6}$ Krismanto, Beberapa Teknik, Model dan Strategi dalam Pembelajaran. (Yogyakarta: PPPG. 2003)

Vol. 22 Nomor. 1 Januari 2011 
Inquiry Training, Oleh: Moh. Turmudi

inkuiri dan studi mandiri. Pemanfaatan Model pembelajaran inkuiri sangat cocok untuk pengaturan kelas terbuka, di mana peran guru adalah sebagai manajer pembelajaran dan monitor. ${ }^{7}$

Pada tahap awal penyelidikan peran guru adalah untuk memilih (atau mengkonstruk) situasi masalah, untuk mewasiti inkuiri sesuai dengan prosedur inkuiri, untuk menangga Pembelajaran Inkuiri pertanyaan penyelidikan siswa dengan informasi yang diperlukan, untuk membantu peneliti awal menetapkan fokus atas penyelidikan mereka, dan untuk memfasilitasi diskusi tentang situasi masalah di kalangan siswa.

\section{Prinsip Reaksi}

Reaksi terpenting dari guru terjadi selama fase kedua dan ketiga. Selama tahap kedua tugas guru adalah membantu siswa untuk bertanya, tetapi tidak membantu penyelidikan untuk mereka. Jika guru mengajukan pertanyaan-pertanyaan yang tidak dapat dijawab dengan ya atau tidak, dia harus meminta siswa untuk memfaraprasekan pertanyaannya sehingga mendorong mereka untuk mengumpulkan data yang berhubungan dengan situasi masalah. Jika perlu guru dapat, inkuiri berlangsung terus dengan memberikan informasi baru untuk kelompok yang berfokus pada peristiwa masalah tertentu atau dengan memberikan pertanyaan. Selama tahap terakhir, tugas guru adalah untuk menjaga penyelidikan diarahkan pada proses penyidikan itu sendiri. ${ }^{8}$

Sistem Pendukung: Dukungan optimal adalah seperangkat bahan yang menantang, dan sumber belajar yang berhubungan dengan masalah. relatif mudah bagi guru guru untuk mengembangkan sendiri bahan inkuiri.

\section{Penerapan}

Meskipun pelatihan penyelidikan pada awalnya dikembangkan untuk ilmu alam, prosedur ini dapat digunakan dalam semua bidang

\footnotetext{
${ }^{7}$ Eggens P \&Kauchak, D. Educational Psychology Windows on Classroom, International Edition New (Jersey: Person Education. Inc. 2004)

${ }^{8}$ Richard, A.S. \& Patricia A.S., Group Process In The Classroom (7 th.Ed), USA Time Mirror Hygler Education Group Inc. 199
} 
Inquiry Training, Oleh: Moh. Turmudi

studi, toPembelajaran Inkuirik apa saja yang dapat dirumuskan menjadi suatu situasi membingungkan merupakan bakal untuk pembelajaran inkuiri. Dalam literatur, pembunuhan misteri dan cerita-cerita fiksi ilmiah atau plot merupakan situasi membingungkan yang sangat baik. Artikel koran tentang situasi yang aneh atau tidak mungkin dapat digunakan untuk membangun peristiwa stimulus. Salah satu penulis berada di sebuah restoran Cina beberapa waktu yang lalu dan bingung atas pertanyaan, "Bagaimana keberuntungan ada di dalam kue keberuntungan, sebab dia tidak tampak terbakar atau dimasak dengan cara apa pun?" Hal seperti itu ada di antara kita dan akan baik dijadikan topik pembelajaran inkuiri untuk anak-anak. Ilmu-ilmu sosial juga menawarkan berbagai kemungkinan untuk pembelajaran inkuiri.

Pengembangan situasi membingungkan merupakan pekerjaan kritis, karena pekerjaan tersebut mengubah isi kurikulum menjadi masalah untuk dieksplorasi, pada saat benda-benda dan bahan lainnya tidak tersedia atau sesuai dengan situasi masalah, kami merekomendasikan bahwa guru membuat pernyataan masalah bagi siswa dan lembar fakta untuk diri mereka sendiri. Pernyataan masalah menggambarkan peristiwa tidak sesuai (discrepant) danberbagi informasi dengan siswa. Lembar fakta memberikan guru informasi lebih lanjut tentang masalah, dan guru menggunakannya untuk menanggapi pertanyaan-pertanyaan siswa.

\section{Dua Masalah Situasi}

Dalam antropologi siswa memiliki masalah merekonstruksi peristiwa budaya. Untuk kelas studi sosial instruktur menuliskan perumusan masalah lembar fakta siswa berdasarkan isu antropologi. Guru menyatakan kepada siswa sebagai berikut.

\section{Rumusan Masalah}

Peta ini menunjukkan sebuah pulau di tengah-tengah danau. Pulau terhubung ke pantai dengan jalan lintas yang terbuat dari tumpukan batu di dasar danau sampai tumpukan mencapai permukaan. Kemudian batu yang diratakan diletakkan untuk membuat jalan. Danau ini dikelilingi oleh pegunungan, dan tanah datar hanya ada dekat danau. Pulau ini diselimuti dengan bangunan yang dindingnya masih tegak 
Inquiry Training, Oleh: Moh. Turmudi

berdiri walaupun atapnya telah musnah. Pulau ini benar-benar tak berpenghuni.

Tugasmu menemukan apa yang terjadi pada orang yang tinggal di sana. Apa yang menyebabkan tempat itu kosong dari manusia? Saat siswa melakukan Inquiry instruktur menggunakan lembar fakta berikut sebagai menjawab pertanyaan siswa.

\section{Umur Tingkat Adaptasi}

Pembelajaran Inkuiri dapat digunakan dengan semua tingkatan umur, tetapi Pembelajaran Inkuiri setiap kelompok umur memerlukan penyesuaian. Pembelajaran Inkuiri digunakan dengan sukses dengan anak-anak TK dan mengalami kesulitan dengan anak kelas ketiga. Seperti banyak aspek lain dari mengajar, setiap kelompok dan setiap siswa adalah unik. Namun, ada beberapa cara untuk menyederhanakan model sampai siswa dapat terlibat dalam semua fase.

Dengan anak-anak sangat muda cara terbaik adalah menjaga isi dari masalah sederhana, mungkin dengan lebih menekankan pada penemuan dibandingkan pada prinsip seba-akibat. Situasi Masalah seperti berikut adalah sesuai. Seperti: "Apa yang ada dalam kotak ini?", “Apakah halini tidak biasa?", "Mengapa satu telur gulung berbeda dari yang lain?". Satu guru kita tahu menunjukkan murid-muridnya gambar tupai terbang dari sebuah majalah untuk guru sains. Karena kebanyakan dari kita percaya hewan tidak terbang, ini benar-benar peristiwa yang lain (unik). Dia meminta para siswa untuk datang dengan penjelasan fenomena melalui prosedur Inkuiri.

Banyak buku-buku ilmu pengetahuan untuk anak-anak dipenuhi dengan eksperimen sain sederhana, banyak diantaranya cocok untuk kelas SD. Cerita misteri dan teka-teki cocok untuk menstimulasi anakanak kecil. Cara lain untuk mengadaptasi Pembelajaran Inkuiriuntuk anak-anak adalah dengan menggunakan materi visual, alat peraga memberikan kontribusi, yang menyederhanakan rangsangan dan mengurangi persyaratan untuk memori. Hal ini berguna untuk tujuan tertentu hanya satu atau dua sesi Pembelajaran Inkuiritunggal. Pada tahap awal (dengan siswa dari segala usia) adalah baik untuk memulai dengan permainan sederhana yang memerlukan pertanyaan ya-tidak. Permainan ini akan memberikan keyakinan siswa bahwa mereka dapat 
Inquiry Training, Oleh: Moh. Turmudi

merumuskan pertanyaan dan menghindari pertanyaan teori langsung. Beberapa guru kita tahu menggunakan tas misteri, yang lain bermain 'Saya memikirkan sesuatu yang saya kenakan. Coba tebak apa itu?'Permainan tebak-tebak seperti ini juga memberikan latihan bagi siswa dalam membedakan pertanyaan teori (Apakah ini baju Anda?) Dari pertanyaan-pertanyaan tentang atribut (Apakah itu terbuat dari kapas?). Kami menyarankan memperkenalkan dan menekankan setiap elemen Penyelidikan secara terPembelajaran Inkuirisah. Pada awalnya semua pertanyaan ya-tidak mungkin dijawab. Kemudian siswa dapat diminta untuk mengubah pertanyaan teori mereka untuk percobaan. Satu per satu kendala Inquiry diperketat pada saat siswa diajarkan masing-masing elemen. Mencoba untuk menjelaskan dan memperkuat semua unsur elemen sekaligus hanya akan menciptakan kegagalan siswa dan guru.

Siswa yang lebih tua lebih mampu menangani proses inkuiri sendiri, dan mata pelajaran utamanya sains lebih siap digunakan PembelajaranInkuiri. Di sisi lain, usia dan jenis kelamin dapat menghambat faktor dalam proses. Walaupun ada banyak peristiwa unik lebih cocok dalam kurikulum kelas atas SD dan SMP/SMA, biasanya diperlukan bagi guru untuk mengkonversi bahan-bahan yang tersedia dari modus ekspositoris ke modus inkuiri yaitu, untuk menciptakan peristiwa unik.

\section{Lingkungan Belajar Adaptasi}

Seperti model lainnya, terutama Model Pengolahan Informasi, Inkuiri dapat diajarkan dalam setting arahan-guru atau diselipkan ke dalam pembelajaran lebih mandiri, lingkungan belajar terpusat. Peristiwa unikdapat dikembangkan melalui media cetak, film, atau sarana audio, dan kartu tugas yang mengarahkan siswa untuk merespon sesuai dengan model dapat dikembangkan. Inkuiri dapat dilakukan selama beberapa hari, dan hasil Inkuiri siswa dapat disampaikan kepada siswa lain. Siswa harus memiliki akses ke sumber belajar yang tepat, dan mereka mungkin bekerja sama dalam kelompok, atau siswa dapat mengembangkan peristiwa unik dan melakukan sesi Inkuiri bersama sebayanya.

Vol. 22 Nomor. 1 Januari 2011 
Inquiry Training, Oleh: Moh. Turmudi

\section{Langkah-LangkahPelaksanaanPembelajaranInkuiri}

Proses pembelajaran inkuiri dilakukan melalui tahapan-tahapan sebagai berikut:

1. Merumuskan masalah; kemampuan yang dituntut adalah : (a) kesadaran terhadap masalah; (b) melihat pentingnya masalah dan (c) merumuskan masalah.

2. Mengembangkan hipotesis; kemampuan yang dituntut dalam mengembangkan hipotesis ini adalah : (a) menguji dan menggolongkan data yang dapat diperoleh; (b) melihat dan merumuskan hubungan yang ada secara logis; dan merumuskan hipotesis.

3. Menguji jawaban tentatif; kemampuan yang dituntut adalah : (a) merakit peristiwa, terdiri dari : mengidentifikasi peristiwa yang dibutuhkan, mengumpulkan data, dan mengevaluasi data; (b) menyusun data, terdiridari : mentranslasikan data, menginterpretasikan data dan mengkasifikasikan data.; (c) analisis data, terdiridari : melihat hubungan, mencatat persamaan dan perbedaan, dan mengidentifikasikan trend, sekuensi, dan keteraturan.

4. Menarik kesimpulan; kemampuan yang dituntut adalah: (a) mencari pola dan makna hubungan; dan (b) merumuskan kesimpulan

5. Menerapkan kesimpulan dan generalisasi

\section{Keunggulan dan Kelemahan Pembelajaran Inkuiri}

1. Pembelajaran inkuiri merupakan pembelajaran yang banyak dianjurkan, karena memiliki beberapa keunggulan, di antaranya:

a. Pembelajaran ini merupakan pembelajaran yang menekankan kepada pengembangan aspek kognitif, afektif, dan psikomotor secara seimbang, sehingga pembelajaran melalui pembelajaran ini dianggap jauh lebih bermakna.

b. Pembelajaran ini dapat memberikan ruang kepada siswa untuk belajar sesuai dengan gaya belajar mereka.

c. Pembelajaran ini merupakan strategi yang dianggap sesuai dengan perkembangan psikologi belajar modern yang menganggap belajar adalah proses perubahan tingkah laku berkat adanya pengalaman. 
d. Keuntungan lain adalah dapat melayani kebutuhan siswa yang memilikikemampuan di atas rata-rata. Artinya, siswa yang memiliki kemampuan belajar bagus tidak akan terhambat oleh siswa yang lemah dalam belajar.

2. Di samping memiliki keunggulan, pembelajaran ini juga mempunyai kelemahan, di antaranya:

a. Sulit mengontrol kegiatan dan keberhasilan siswa.

b. Sulit dalam merencanakan pembelajaran oleh karena terbentur dengan kebiasaan siswa dalam belajar.

c. Kadang-kadang dalam mengimplementasikannya, memerlukan waktu yang panjang sehingga sering guru sulit menyesuaikannya dengan waktu yang telah ditentukan.

d. Selama kriteria keberhasiJan belajar ditentukan oleh kemampuan siswa menguasai materi pelajaran, maka strategi ini tampaknya akan sulit diimplementasikan 
Inquiry Training, Oleh: Moh. Turmudi

\section{Daftar Pustaka}

Cochran, Rachel et al.(2007). The impact of Inqury-Based on Context Knowledge and Classroom Practice. Journal. Tersedia: http://www.rume.org/crume2007/ papers/cochran-mayer$\underline{\text { mullins.pdf }}$

Costa A.L., Teaching for Intelegence Arlington Heights, (Illinois: Skylight Training and Publishing Inc., 1999)

Eggens P \&Kauchak, D. Educational Psychology Windows on Classroom, International Edition New (Jersey: Person Education. Inc. 2004)

Jacob, E. Cooperative Learning In Contact : An Educational Innovation In Everyday Classroom State University of (New York Press. Albany. 1999)

Joni, R.T. Pendekatan Cara Belajar Siswa Aktif, dalam Conny R. Setiawan Pendekatan Pembelajaran di Sekolah, Jakarta 1993a

Joice, B. \& Weil, M. Model of Teaching Englewood ellifts (N.J.: Prentice Hall Inc. 1980)

Krismanto, M.Sc. Beberapa Teknik, Model dan Strategi dalam Pembelajaran. PPPG.Yogyakarta, 2003)

Richard, A.S. \& Patricia A.S., Group Process In The Classroom (7 th.Ed), USA Time Mirror Hygler Education Group Inc. 1993

Sanjaya, Wina. Strategi Pembelajaran Berorientasi Standar Proses Pendidikan. (Jakarta: Kencana Prenada Media Group. 2008)

Slavin, Robert. E. Cooperative Learning; Teori, Risetdan Praktik. (Bandung: Nusa Media, 2008)

Tim MKPBM, Strategi Pembelajaran Kontemporer. (Bandung: JICA, 2008) 